\title{
Exposing the Colonial Exhibition
}

\section{Dutch Anti-Colonial Activism in a Transnational Context}

\author{
Marin Kuijt, Utrecht University, Utrecht, the Netherlands
}

\section{Abstract}

In 1932 anti-colonial activists from Surinam, Indonesia and the Netherlands formed a committee to oppose the Indonesian Exhibition staged in The Hague, the Netherlands. They called themselves the Anti-Koloniale Tentoonstellings Actie (AKTA; AntiColonial Exhibition Action). The Dutch government used the exhibition to spread a pro-colonial message. The committee confronted the Dutch audiences, on the other hand, with a radical critique of colonialism. In recounting AKTA's history for the first time ever, I focus on the writings of the committee and ask why the committee criticised the exhibition in the ways it did. I show how AKTA's criticism of the Indonesian Exhibition was profoundly influenced by anti-colonial activism in Surinam, Harlem, Indonesia, Holland and Paris. The committee fashioned its activism on anti-colonial examples from these contexts, and I introduce the term discursive repertoire of contention to describe this phenomenon - that is, AKTA drew on the archive of anti-colonial statements made before it. Some historians have painted a picture of the anti-colonial world of the early 1930s as a time when ideological boundaries were hard. The case of AKTA complicates this picture on a regional level. AKTA was both a regional actor and part of a large international anti-colonial network, and it traversed ideological boundaries within this network.

Keywords: Anti-colonial activism, colonial exhibitions, League Against Imperialism, transnational history of the Dutch empire

In 1932 a diverse group of anti-colonial activists joined forces in The Hague. The activists from the Netherlands, Surinam and Indonesia adhered to different ideologies: some were communists, whereas others were anarchists or anti-militarists. They formed a committee to contest the Indonesian Exhibition staged in The Hague during that summer. The committee saw the exhibition as an 'advertisement' campaign for 'imperial rulers' (Van Loon, 1932a). During the summer of 1932, the activist told a radically different story about colonialism than the exhibition did. They called themselves the Anti-Koloniale Tentoonstellings Actie (AKTA; Anti-Colonial Exhibition 
Action) (Van Loon, 1932a). The story of these anti-colonial activists has long been forgotten.

The current image of the Dutch anti-colonial landscape of the early 1930s is that the main anti-colonial actors, such as the Communist Party, refused to cooperate with anti-colonial groups that did not occupy the same ideological position. This partisan climate originated from the Soviet Union, which ordered communist parties throughout the world to cease collaborating with non-communists from 1928 onwards (Carr, 1983: 385). The historian Gerrit Voerman (2001: 12) claims that the Dutch Communist Party obediently followed this line. Klaas Stutje (2015b: 210) has argued that in this antagonistic climate 'cross-political cooperation against colonialism came to an end'. This may be true on the national level. However, this article shows that on a regional level, anti-colonial 'cross-political cooperation' was still possible in the early 1930s. AKTA was an open organisation that included activists from different political persuasions. The cause of anti-colonialism, which mainly consisted in pointing to the cruel and exploitative nature of Dutch colonial rule and a commitment to the independence of the colonies, resonated among different left-wing groups and had the potential to unite them - even in the early 1930s, fraught with ideological tension as those years were.

AKTA's main goal was to protest the Indonesian Exhibition taking place in The Hague in 1932. The committee organised public rallies and neighbourhood meetings. Unfortunately, no records of these public activities have survived. What remains of AKTA is an archive full of internal correspondence, financial dealings and, most importantly, press releases and two pamphlets. Therefore, in this article, I focus on AKTA's discourse and pose the question: why did AKTA criticise Dutch colonialism in the ways it did. This close attention to AKTA's discourse will bring forth the thought, message and aims of this forgotten anti-colonial organisation. Through this examination, the transnational contacts and exchanges that formed AKTA's activism will also be brought to light. I do this by tracing distinct textual clues and through reconstructing the social networks of AKTA's most prominent members. Apart from the material of AKTA's archive, I draw on a wide range of sources, from the letters of the Indonesian Exhibition's organisation to French anti-colonial newspapers.

In between the First World War and the Second World War, Europe witnessed a rising tide of anti-colonial activism, both in the colonies and in the metropole (Boittin, 2010): bolstered anti-colonial activism in Europe, the metropole, by committing itself both ideologically and financially to the anti-colonial struggle (Young, 2016: 120). The 
Soviet Union and its international communist platform, the Third International, funded subsidiary organisations such as the League Against Imperialism to support and connect anti-colonial activists in Europe (Petersson, 2014). Anti-colonial activism in the interwar period could take on many forms, such as the organisation of congresses or public rallies. A remarkable form of interwar anti-colonial activism was the contestation of colonial exhibitions. At such exhibitions, colonial powers put their empire 'on display' and legitimised their colonial projects through the mission civilisatrice, or white man's burden, trope (Hoffenberg, 2001: xxii; Morton, 2000: 5-8). These exhibitions, however, were also sites of resistance. In Great Britain, two colonial exhibitions were contested by African students and a coalition of left-wing groups (Britton, 2010). In opposition to the Parisian colonial exhibition of 1931, surrealists, communists and radical black organisations, with the help of the League Against Imperialism, staged a full counter exhibition (Palermo, 2009). In this article, I recount the history of AKTA's contestation of the Dutch Indonesian Exhibition.

Historians studying interwar anti-colonial activism in Europe have connected these protests to the decolonisation that occurred after the Second World War (Goebel, 2015: 279-80; Petersson, 2014: 52). Many of the actors involved in the interwar anticolonial scene in Europe would become the anti-colonial fighters, heroes and firstgeneration rulers of their independent countries. Consider, for example, that Jawaharlal Nehru and Mohammed Hatta attended the first congress of the League Against Imperialism (Petersson, 2014: 59). After the Second World War and wars of decolonisation, they would go on to become, respectively, India's first prime minister and Indonesia's first vice-president.

The scholars of interwar anti-colonialism have also excavated the transnational networks and exchanges underlying interwar anti-colonial activism in the metropole. Frederik Petersson has unearthed the 'lost history' of the League Against Imperialism and its function as a 'hub' in anti-colonial networks (Petersson, 2014: 50). Jennifer Boittin and Michael Goebel have both devoted a book to the emergence of radical rejections of empire in the international communities of interwar Paris (Boittin, 2010; Goebel, 2015). Similar communities and their politics have been studied by Aitken Robbie and Eve Rosenhaft in Germany (Aitken and Rosenhaft, 2013). All these works focus on the transnational networks and communities underlying anti-colonial thought and practice. Activists exchanged ideas and experiences within these networks and communities. These exchanges were formative of the horizons of anticolonialists, against which they defined their political goals, moral judgements and strategic decisions. Through the exchange of ideas and experiences, new alliances and 
practices emerged. Students from Uruguay and Argentina, for example, met each other in interwar Paris, and these contacts gave rise to feelings of regional solidarity (Goebel, 2015: 130). In the words of Michael Goebel, these historians have thus examined 'the social bedrock of ideas' (Goebel, 2015: 3). This focus has proved to be fertile. It has yielded insights into the transnational contacts, local allegiances and contingencies that animated the emergence of anti-colonial action and thought in intricate ways. For the Dutch context, Klaas Stutje has similarly researched the complicated politics, contacts and networks of colonial students in the Netherlands (Stutje, 2015a; 2015b; 2017). In this article, I build on these publications and employ a transnational perspective. However, the case of AKTA also nuances the current image of the early 1930s in Holland as a time where ideologically diverse coalitions against colonialism no longer existed.

In this article, I firstly situate AKTA in the global and local anti-colonial landscape. I then recount AKTA's internal history. After that, AKTA's discourse takes centre stage. In its pamphlets, AKTA stated that Dutch colonialism was an oppressive capitalist project. By comparing this message to other anti-colonial texts from the interwar period, it becomes clear that AKTA was influenced by diverse transnational anticolonial contexts such as Paris, Indonesia, Harlem and Surinam. These diverse contexts inspired AKTA and provided the committee with what I call a discursive repertoire of contention. These precursors bestowed lessons in anti-colonial activism on AKTA.

\section{Historical context}

Until the beginning of the Second World War, the Dutch colonial empire spanned Surinam, the Antilles and the Indonesian archipelago. During a period ranging from the end of the nineteenth century until the 1930s, the Dutch government expanded its Indonesian territories through a series of bloody campaigns (Wielinga, 2015: 187). A paternalistic endeavour to educate and raise the peoples of Indonesia according to Western standards accompanied the harsh military action (Bloembergen and Raben, 2009: 7-8). This tightening of colonial rule led to greater Indonesian resistance against Dutch colonial rule. The most radical expressions of Indonesian discontent was the communist insurrection of 1926 . The Dutch government forcefully repressed this rebellion and sent its leaders to the infamous concentration camp of Boven Digoel. 
Whereas most European states, like the Dutch, tried to suppress anti-colonial movements, the Soviet Union actively supported these movements. Following Lenin, the Soviet Union maintained that imperialism is a product of capitalism (Noonan, 2017). According to this reasoning, the end of an empire is a necessary condition for the end of capitalism, hence the commitment of the Soviet Union to anti-colonial struggles all over the world (Young, 2016: 125). The Third International, or Comintern, was an international congregation of communists. Through this agency, communist organisations from all over the world set their policy and strategies together with the Soviet Union. From 1928 onwards, the Comintern advanced an antagonistic line (Carr, 1983: 385). This meant that all non-communists were to be vehemently opposed. This directly impacted the anti-colonial organisations and activists supported by the Comintern. They had to cease cooperating with non-communists.

The League Against Imperialism was one of the Comintern's anti-colonial organisations. The Soviet Union tasked the League with stimulating anti-colonial protests throughout Europe (Petersson, 2013, vol. 2). According to Petersson (2014: 50), the League functioned as a 'hub' that connected different anti-colonial groups, and through this function enabled new coalitions to take shape and new protests to take place. The antagonistic strategy was a disaster for the League. By refusing to cooperate with non-communists, and expelling them from its ranks, the League lost most of the prestige it had gained (Petersson, 2014). Therefore, the League returned to a conciliatory approach, or popular-front strategy, in 1930, contrary to all other organisations associated with the Comintern such as the Dutch Communist Party (Petersson, 2013, vol. 2: 770). One of the most visible protests subsequently initiated by the League Against Imperialism was the counter exhibition staged in Paris in 1931 (Ezra, 2000: 22-26). Through this exhibition, the League brought together the French Communist Party, surrealists and anti-colonial black groups, such as the Union Travailleurs Nègres (Palermo, 2009: 28). These groups staged a counter exhibition as a protest against the official colonial exhibition staged in Paris that same year. The Dutch government contributed to the official French colonial exhibition by filling a pavilion, which was transported to The Hague after the Paris exhibition had ended (Bloembergen, 2001: 257). There the city turned the pavilion into the independent Indonesian Exhibition in 1932 (Municipal Secretary, 1932).

From 15 May 1932 up until 30 September 1932, people could visit the Indonesian Exhibition in a public park in The Hague. The Indonesian Exhibition was a spectacle; it consisted of seven buildings, all built in different styles of Indonesian colonial architecture. Visitors could enter the 'Sumatran house' where local garments were on 
display, a 'Balinese courtyard' with a temple and different Buddha statues in it, have dinner in the 'Indonesian restaurant' or visit a show of the 'Siamese dancers' (Leidraad voor de Indische Tentoonstelling, 1932: 29-34; Indische Tentoonstelling, 1932a). The spectacle was a success. The exhibition attracted large crowds: in total 420,294 persons visited the exhibition (Indische Tentoonstelling, 1932b). It had a clear propagandistic purpose; it meant to depict the Dutch as the conscientious caretakers of Indonesia. For example, a manual for teachers visiting the exhibition with their school children states that 'the exhibition clearly depicts [...] [that] the Netherlands try to live up to their obligations to the indigenous [Indonesian] population. Especially with regards to healthcare' (Leidraad voor de Indische Tentoonstelling, 1932: 28). Visitors should learn from the exhibition that the Dutch rulers act as benevolent parents caring for the health and wellbeing of their colonial offspring.

\section{AKTA}

Local anarchist and anti-militarist groups, however, drew an entirely different lesson from the exhibition. At the end of May, five of them united under the banner of AKTA to oppose the Indonesian Exhibition (Van Loon, 1932b). They saw the Indonesian Exhibition as an 'advertisement' for 'the imperial rulers' (Van Loon, 1932a). Among these anarchist groups was a labour union and an anti-war organisation. All these groups were small and operated on the fringes of the Dutch political landscape (Ramaer, 1983: 12). Because they were non-communists, the organisations and AKTA were not linked to the Comintern. The anarchists absolutely opposed all forms of structured governance. From this position, their commitment to anti-colonialism naturally followed, since colonialism is a form of hierarchical, structured governance.

At the end of June 1932, a consortium of three international communist groups joined AKTA. Firstly, the Dutch section of the League Against Imperialism (Van Loon, 1932c). The League sent Anton de Kom as a representative to AKTA. De Kom was a black radical writer and activist from Surinam with strong sympathies for communism. In the early 1930s, he published various articles in communist magazines as well as his well-known anti-colonial history of Surinam, Wij slaven van Surinam (Boots and Woortman, 2009: 91-98). Through his writing and activism in the metropole, de Kom acquired fame and a following in Surinam (Fatah-Black, 2017: 479-83). In the summer of 1932, de Kom played a central role in AKTA. The other two organisations were radical communist associations of Indonesian students studying at Dutch universities, the Sarekat Peranakan Tionghoa Indonesia and the Perhimpunan Indonesia. Both groups vocally championed Indonesian independence and maintained close contacts 
with the Dutch Communist Party. (Poeze, 1989: 273; Poeze et al., 1986: 245). One of their members even got elected into parliament as a member of the communist faction.

Because of the antagonistic line of the Comintern, major players in the Dutch anticolonial field, such as the Social Democratic Party and the Communist Party, no longer officially cooperated with each other (Stutje, 2015b: 210). This led Stutje to the observation that 'cross-political cooperation' directed against colonialism disappeared in the early 1930s. The antagonistic sphere of those years, however, did not preclude a local alliance between anarchists and anti-militarists on the one hand and international communist groups on the other. This alliance was partly born out of necessity and practical considerations, the small anarchist organisations could use help well. It was also based, however, on a shared commitment to 'the struggle against all forms of imperial and national domination' (Van Loon, 1932c, emphasis original). In the early 1930s, anti-colonialism was thus still a cause that could inspire cooperation between different left-wing factions.

\section{Discourse}

AKTA published two pamphlets. The first one was published in June 1932 when AKTA was dominated by anarchists (AKTA,1932a). The second pamphlet was published in August when the international communists had joined (AKTA 1932b). In these pamphlets, AKTA paints a very different picture of Dutch colonialism than the Indonesian Exhibition did. The first pamphlet was printed on A4-size paper and AKTA ordered between 6,000 and 12,000 copies of the pamphlet, indicating serious outreach efforts (Van Loon, 1932d).

The first pamphlet identified Dutch colonialism as an elite enterprise, within which profit was of paramount importance and human suffering of no concern (AKTA, 1932a). According to AKTA, the capitalist drive for profits led to the vicious repression of the colonised Indonesians. In a remarkable passage in the pamphlet, for instance, AKTA stated that Dutch colonialism is nothing but: 'Dutch theft, Dutch murder, Dutch rape, Dutch arson, Dutch torture and terror' (AKTA, 1932a: 1, emphasis original). AKTA used in this passage some of the harshest possible words to describe Dutch colonial rule. There does not seem to be a horror not inflicted on the Indonesian people by the Dutch. In such passages, AKTA tried to convince the reader that their sympathies should lie with the colonised Indonesians. AKTA argued that there is only one way in which this can be stopped. The pamphlet ends with a call for the 
immediate independence of Indonesia: 'Indonesia separate from Holland - NOW!' (AKTA, 1932a: 2). The 'NOW!' in this slogan adds a sense of urgency to AKTA's message, making it clear to the reader that they should take immediate action against colonialism.

The second pamphlet reiterated this message, but it also raised one new issue in the pamphlet: race (AKTA, 1932b). The second pamphlet continuously pointed to the racism inherent in Dutch colonialism and also subverted the traditional colonial racial hierarchy in which white is superior to black. This becomes evident in the following excerpt taken from a paragraph on the killing of 'coolies', Indonesian indenture workers: 'The murder of a coolie by white "civilisers" is either not registered or [it is] celebrated' (AKTA, 1932b: 8). In this fragment, AKTA showed that whites can wantonly kill non-whites. This racism, according to the committee, shows that the 'white "civilisers"' are not civilised at all, rather they behave like beasts (AKTA, 1932b: 8).

The attention AKTA started paying to race is most likely a consequence of the arrival of the international communist organisations within the committee. Anton de Kom, the delegate of the League Against Imperialism, was engaging critically with race, racism and empire in the 1930s (Boots and Woortman, 2009: 152-53). In his anticolonial history of Surinam, de Kom thematises the issue of race in relation to the Dutch empire extensively. He writes, for instance, that although it may seem that '[t]he white population reached the highpoint of civilisation in its parties', it was nothing more than a display of 'debauchery' at the expense of 'the slaves' and 'the silent black mob' (De Kom, 2017: 44). De Kom's criticism of 'white civilisation' must, partly, be inspired by his own experience as a black man living under Dutch colonial rule. This example then shows that De Kom's Surinam influenced AKTA's activism in the metropole. I now turn to the other contexts, both transnational and regional, that influenced AKTA's message.

\section{Tracing connections}

De Kom did not bring only his own experience of colonial rule with him to AKTA, he also brought his knowledge of contemporary American criticisms of race and empire. De Kom knew Otto Huiswoud and met him regularly during the 1930s (Oostindie and Maduro, 1986: 63). Huiswoud was a Surinam communist who had lived in the United States during the 1920s. During their conversations, Huiswoud must have told de Kom about the American Blood Brotherhood, of which he was a member. The American Blood Brotherhood was a secretive black communist organisation from Harlem, New 
York, which devoted attention to the 'economic nature of the African American struggle' (Kuykendall, 2002: 17). De Kom was fascinated by what Huiswoud told him; his biographers note that de Kom's writings display remarkable similarities to those of black writers from Harlem (Boots and Woortman, 2009: 152-53). In the second pamphlet, AKTA referred to the American Blood Brotherhood: the committee agreed with the American Blood Brotherhood that the downfall of the white oppressors is imminent (AKTA, 1932b: 12).

The Indonesian anti-colonial politics also influenced the committee. The communist Indonesian students spoke at AKTA's neighbourhood meetings (Van Loon, 1932e). Unfortunately, because of the lack of sources, it is unknown what they said during these meetings. However, their involvement shows that they made their mark on AKTA's activism. The Indonesian context also came to AKTA in another way. One of AKTA's anarchist members, Gé Nabrink, was closely associated with Henk Sneevliet (Van Sijl, 2001). Sneevliet was one of the founders of the precursor to the Indonesian Communist Party, and he vocally advocated Indonesian independence (Perthus, 1976), Through the personal connection of Nabrink and Sneevliet, knowledge of the situation in Indonesia most likely also reached AKTA.

Throughout the interwar period, there were contacts between French anti-colonial groups and the Dutch anti-colonial left. In 1925 a member of the Perhimpunan Indonesia moved to Paris to establish contacts with activists and organisations there, such as the anti-colonial newspaper founded by Ho Chi Min (Stutje, 2015b: 205). From the end of the 1920s onwards, both countries had sections of the League Against Imperialism. The organisation fulfilled its role as 'hub' that Petersson has described by connecting the countries' anti-colonial networks. (Petersson, 2014: 50). As in the Netherlands in 1932, in 1931 the League Against Imperialism was involved in antiexhibition protests in Paris against the French colonial exhibition. One of the radical black organisations involved in these anti-exhibition protests, the Union de Travailleurs Nègres, published in its newspaper, Le Cri des Nègres, an article that reflected on the official colonial exhibition. In this article, the newspaper wrote that 'alcoholism and syphilis' are the 'defects of the "civilised metropoles”' (Rosso, 1931). One year later, AKTA wrote in its first pamphlet that ' $[\mathrm{t}]$ he civilisation brought by the Netherlands to Indonesia consists of gin and syphilis' (AKTA, 1932a: 2, emphasis original). This strong similarity between the two phrases suggests that AKTA was well informed about the contestation of the Parisian colonial exhibition and that the French protests served as a source of inspiration to AKTA. 
The most important context to AKTA, however, was the Dutch anti-colonial left. This was the direct context from which the committee emerged and in which it operated. AKTA relied on the infrastructure and support of the anti-colonial left in Holland for many things, such as the printing of its pamphlets. For example, they wrote to a communist member of parliament for support when the municipal council of The Hague refused to grant the committee access to a public space for one of AKTA's meetings (Van Loon, 1932f). A member of the Communist Party also collected signatures in support of AKTA's protests (AKTA, n.d.). These contacts show that, on a local level, the Communist Party informally supported rather than antagonised ideological pluriform organisations such as AKTA. The committee must also have been aware of other Dutch anti-colonial actions and also of anti-colonial publications circulating in this scene. Together with Anton de Kom's Surinam, the anti-colonial Indonesian context, the Parisian anti-colonial exhibition and black activism from Harlem, the Dutch metropolitan anti-colonial context influenced AKTA's activism.

\section{A discursive repertoire of contention}

The two contexts closest to AKTA in time and space, the Dutch anti-colonial context and the French anti-exhibition actions, provided AKTA with what I call a discursive repertoire of contention. I derive this term partly from the work of Charles Tilly, who argued that social groups have a 'repertoire of contention' on which they draw when protesting or contesting a social issue (Tarrow, 1993: 283). This repertoire consists of the different forms of political action that the group knows how to use and thinks of as legitimate (Tilly, 2017: 83). For the Rote Armee Fraktion, for example, bombings belonged to their repertoire of contention, whereas this is not the case for current day protesting students. The word 'repertoire' is important because it indicates that, despite the availability of a wide range of forms of protest available to a group, the group will only use a smaller subset of this range. At different times, AKTA drew on different parts of the repertoire. I add the predicate 'discursive' because AKTA's discourse is its only activity that can be studied now (cf. Steinberg, 1998). A discursive repertoire of contention is thus a set of discursive strategies, motifs and themes available to a group for the contestation of a specific issue. I identify five tropes in the repertoire: the call for the immediate dismantlement of empire, the horrors of colonial rule, a call for solidarity amongst workers of different races, characterisation of the of colonialism as an economic or capitalist project and the idea that European civilisations are superior to the cultures of the colonised peoples. 
The first feature of this repertoire I identify is the call for the immediate dismantlement of empire. For instance, The French Union de Travailleurs Nègres wrote in its newspaper that ' $[t]$ he liberation of the colonies should be the principal objective of the colonial workers' (Rosso, 1931). The French surrealists conveyed the same message to metropolitan workers in a pamphlet on the colonial exhibition. They wrote that the French workers should 'demand that the colonies are to be evacuated immediately' (Aragon et al., 1931). On the Dutch parliamentary anti-colonial left, the Dutch Communist Party was the most vocal supporter of the independence of the colonies. The slogan 'Indonesia separate from Holland - NOW!' powerfully encapsulated their views and demands. This phrase was a communist tool for contesting Dutch colonialism. The communists used this tool on different occasions. In 1934, for example, the leader of the parliamentary communist faction, Louis de Visser, shouted 'Indonesia separate from Holland - NOW!' when the Queen entered parliament at the opening of the parliamentary year (Parliament.com, 2019). He was forcefully removed by the police. With bold statements like these, activists question the hegemonic idea that colonies should not become independent in different contexts. AKTA used this slogan at the end of its first pamphlet (AKTA, 1932a: 2).

The second aspect is the constant emphasis laid on the horrors of colonial rule. In 1928 the communist daily De Tribune reported on protests of the radical Indonesian student association the Perhimpunan Indonesia, some of whose members would later become involved in AKTA. The association protested the Dutch concentration camp Boven Digoel in Indonesia where many communists were taken prisoner (De Tribune, 1928: 1). The Perhimpunan Indonesia issued an anti-Boven Digoel motion and the communist newspaper printed it on its front page. One section revolved around the horrors of colonial rule: 'abuse of power, violence and abuse of defenceless political prisoners and their women perpetrated by the soldiers tasked with guarding them and a hostile government are out of control' (De Tribune, 1928). Some years later, the newspaper Le Cri des Nègres wrote that if the official colonial exhibition in Paris had depicted colonialism 'in all its nudity', then it should have shown the 'dexterity of the firing squads' (Saumane, 1931). In 1932 AKTA again took up this trope in its pamphlets. It thematised colonial oppression in passages such as 'Dutch theft, Dutch murder, Dutch rape, Dutch arson, Dutch torture and terror' (discussed above; AKTA, 1932a: 2).

The third tactic in the repertoire is a call for solidarity among workers of different races. In 1920 the newspaper of the Dutch Communist Party De Tribune printed on its front page a speech delivered by a Dutch communist to the Comintern (De Tribune, 
1920: 1). In this speech, the Dutch communist, who is not named in the article, made an appeal: 'white and brown slaves of the entire earth! Together destroy the tyranny of capital' (De Tribune, 1920: 1). In 1926 the paper reiterated this appeal when it covered the communist insurrections in Indonesia. In an article on the insurrection, the newspaper tried to get the Dutch workers to support the Indonesian communists by telling them that: 'the struggle of our brown brothers is also our struggle' (De Tribune, 1926a: 1). Surrealists, along with other anti-colonial activists in France, tried to win over their metropolitan audience for their anti-colonial politics in a similar fashion by telling their readers in a pamphlet that the 'colonial peoples are, in fact, the allies of the global proletariat' (Aragon et al., 1931: 1). In its second pamphlet, AKTA wrote: 'fight for the right to life of the proletariat of all colours, on every place on earth!' (AKTA, 1932b: 15). This appeal thus had a strategic function. It was meant to get the metropolitan workers to support, and thus to strengthen, anti-colonial activism.

The characterisation of the of colonialism as an economic or capitalist project is the fourth aspect of the discursive repertoire of contention. In 1926 the Dutch communist newspaper De Tribune wrote that the colonial government of Indonesia is but 'the representative of Dutch capitalism' (De Tribune, 1926b: 1). The Dutch communist Henk Sneevliet made the same connection between colonialism and capitalism in a pamphlet on the threat of a European colonial intervention in China. It would not surprise him, Sneevliet wrote, if the colonial powers of Europe were to expand their empires into China, since ' $\mathrm{t}$ ] he imperialists know very well the endless possibilities available in China for trade and the profitable investment of capital' (Sneevliet, 1984: 52). AKTA employed very similar language in its second pamphlet: 'Only for the profits of the white entrepreneurs, 60 million Indonesians live in hell', implying that colonialism only revolves around making a profit (AKTA, 1932b: 7). This aspect of the discursive repertoire of contention fulfils a similar strategic role to the call for transracial worker solidarity. AKTA used it to convince workers committed to opposing capitalism in the metropole that they also should oppose capitalism in the colony.

The final facet of the discursive repertoire of contention is formed by the subversion of the idea that European civilisations are superior to the cultures of the colonised peoples. A critical remark made by Henk Sneevliet on the Dutch contribution to the Paris colonial exhibition in 1931 exemplifies this theme. Sneevliet writes that '[t]he results of the "civilisation" brought by "us" to Indonesia, or rather, the returns of the theft and murder unleashed on the Indonesian people, were exhibited in Paris' (Bloembergen, 2001: 253). The surrealists agreed with Sneevliet on this matter. According to them, the French colonial subjects put on display in the exhibition 'could 
possibly know better than us the true meaning of human knowledge, love and happiness' (Aragon et al., 1931: 2). AKTA also sarcastically undermined the idea that the Dutch bring progress to Indonesia by stating that '[t]he civilisation brought by the Netherlands to Indonesia consists of gin and syphilis' (AKTA, 1932a: 1). This discursive strategy targeted one of the most important legitimations of empire: the notion of the mission civilisatrice or the white man's burden. By calling this notion into question, AKTA radically critiqued the official message of the Indonesian Exhibition that the Dutch are the caretakers of Indonesia as expressed in the teacher's manual Leidraad voor de Indische Tentoonstelling (1932).

The concept of the discursive repertoire of contention and the comparisons between AKTA's discourse and French and Dutch anti-colonial discourses make tangible the influences of local and transnational contexts on AKTA's activism. The focus on discourse has thus yielded valuable insights into the transnational contacts and exchanges underlying AKTA's activism. The open character of AKTA and the diverse positions of its members is reflected in the diversity of discursive sources and contexts the committee drew upon. Instead of a rigid, ideologically pure organisation, AKTA flexibly drew upon many different sources and examples to compile its message and form its activism. AKTA's writing was influenced by events in Paris and years of Dutch left-wing anti-colonialism, but also by the students and De Kom's direct experiences of the colonial situation in Surinam and Indonesia and radical black activism in America. AKTA was thus both a regional actor and part of a large international anti-colonial network and traversed ideological boundaries within this network.

\section{Conclusion}

The Anti-Koloniale Tentoonstellings Actie was a dissonant voice in Holland during the spring and summer of 1932. The committee confronted the Dutch public with a critical view on the Colonial Exhibition in The Hague and on colonialism. This anti-colonial protest has been overlooked by historians. To gain insights into AKTA's beliefs, ideals, activism and context I paid special attention to its pamphlets and to how the committee characterised Dutch colonialism in these pamphlets. In its discourse, AKTA established that Dutch colonialism was essentially a capitalist exploitative enterprise with strong racist features. It actively drew on a discursive repertoire of contention. That is, AKTA drew on the archive of anti-colonial statements made before it.

By paying special attention to AKTA's discourse, I have been able to trace AKTA's connections to Paris, Indonesia, the United States and Surinam. AKTA's 
characterisations of colonialism were affected by these transnational influences, which were partly mediated by the Indonesian students and Anton de Kom. The Dutch and French anti-colonial contexts most directly shaped AKTA's discourse. These insights into AKTA's network contribute to the work of a group of historians of interwar anti-colonialism. These historians are interested in the contacts and exchanges between different interwar anti-colonial groups (Goebel, 2015; Stutje, 2015a). This article has revealed new connections and exchanges in the interwar anticolonial world. AKTA was thus part of the rising tide of anti-colonialism of the interwar period that foreshadowed and prepared decolonisation after the Second World War. This case study, however, also complicates the image of the early 1930s as a time where the anti-colonial scene was rigidly divided among ideological lines. In many ways, AKTA crossed those lines. Further research could address the impact of AKTA's activism on the Dutch audience and the anti-colonial network of the committee. This could, for instance, be done through a study of newspaper reports about the Indonesian Exhibition.

AKTA radically challenged the contemporary Dutch assumption that the Netherlands should rule distant parts of the world and, as such, can be seen as one of the many sites of resistance to Dutch and European colonialism in the interwar period. This resistance eventually led to the end of Dutch colonial rule in Indonesia and the country's independence shortly after the Second World War. Historians and citizens are still coming to terms with decolonisation and the colonial regimes that preceded it. This article has added AKTA's dissenting voice to the chorus recounting the complicated Dutch and European colonial pasts.

\section{Acknowledgements}

Parts of this article have been presented at the Global History Student Conference 2019 organised by the Freie Universität and Humboldt Universität in Berlin. The author would like to thank Dr Rachel Gillett for all her support. Without her, this article would never have been written. The author would also like to thank the two anonymous reviewers for their comments.

\section{Bibliography}


International Institute for Social History, Amsterdam, Archive Anti-Koloniale Tentoonstellings Actie (Den Haag), ARCHOO234:

AKTA (1932a), 'De Jongeren en de Indische Tentoonstelling', pamphlet, n.p: AKTA. AKTA (n.d.), 'Uitgegeven steunlijsten', list of people collecting signatures for AKTA.

Van Loon, P. (1932a), Letter to the to the I.A.M.V., N.S.V., J.V.A., LAND. Verb. V. Soc. Anarchisten, B.A.S., G.G.B., vrijdenkersver. Dagenraad, N.-H. Prop. Com.

Van Loon, P. (1932b), Letter to the to the secretary of the Landelijk Verbond van Sociaal Anarchisten

Van Loon, P. (1932c), Letter to the secretary of the Liga tegen Imperialisme en voor nationale onafhankelijkheid sectie Holland

Van Loon, P. (1932d), Letter to the secretary of the Nederlandsch Syndicalistisch Vakverbond.

Van Loon, P. (1932e), Letter to Alg. Corr. Bur. v. Dagbl. Den Haag, Aneta Holland Den Haag, Tribune Amsterdam, Vredes Persdienst, Persdienst I.A. K. Haarlem

Van Loon, P. (1932f), letter to L.L.H. de Visser

International Institute for Social History, Amsterdam, Archive Internationale AntiMilitairistische Vereeniging, ARCH00662, 112:

AKTA (1932b), 'Bloedt, Kromo, Bloedt', pamphlet, Krommenie: IAMV.

Municipal Archive The Hague, Haags Gemeentebestuur archief 1851-1936, 3686:

Indische Tentoonstelling (1932a), letter to the Municipality The Hague

Indische Tentoonstelling (1932b), document with number of visitors

Municipal Secretary (1932), letter to the Chief Engineer

Municipal Archive The Hague, Gemeentelijk Museum voor het Onderwijs, 104, 538: 
n.a.. Leidraad voor de Indische Tentoonstelling (1932), booklet about the Indonesian Exhibition for teachers

\section{Newspaper sources}

'De Hollandsche Communisten aan de Volkeren van het Oosten' (1920), De Tribune, 25 October 1920, p. 1, available at https://resolver.kb.nl/resolve? urn=KBDDD02:000204687:mpeg21:p001, accessed 18 February 2019

'Blanke ballast' (1926a), De Tribune, 27-11-1926, p. 1, available at https://resolver.kb.nl/resolve?urn=ddd:010468772:mpeg21:p001, accessed 18 February 2019

'Voor het Recht van den Indonesiër' (1926b), De Tribune, 21 June 1926, p. 1, available at https://resolver.kb.nl/resolve?urn=ddd:010468688:mpeg21:a0020, accessed 21 June 2019

'De Perhimpoenan Indonesia Zij protesteert tegen de hel van Boven-Digoel' (1928), De Tribune, 28 May 1928, p. 1, available at https://resolver.kb.nl/resolve? urn=ddd:010466364:mpeg21:a0020, accessed 7 June 2019

Rosso, S. (1931), 'Alors que l'Exposition se ferme!', Le Cri des Nègres, August 1931, p. 3

Saumane (1931), 'Exposition Coloniale Internationale', Le Cri des Nègres, October 1931, p. 3

\section{Published sources}

Aragon, L., R. Crevel, R, M. Alexandre, G. Malkine, G. Sadoul, A. Thirion, P. Unik, R. Char, P. Éluard, B. Péret and Y. Tanguy (1931), 'Ne Visitez pas l'exposition coloniale', André Breton. available at http://www.andrebreton.fr/work/56600100711050, accessed 29 March 2019

De Kom, A. (2017, fourteenth edition [1934]), Wij slaven van Suriname, Amsterdam: Olympus

Sneevliet, H. (1984), 'Het Chineesche proletariaat in de Chineesche revolutie', in De Winter, T., B. and D. Van der Plas (eds), Internationaal Socialisme: Teksten van Revolutionarire socialisten, Rotterdam: Van Lambaart 
Aitken, R. and E. Rosenhaft (2013), Black Germany: The Making and Unmaking of a Diaspora Community, 1884-1960, Cambridge; New York: Cambridge University Press

Bloembergen, M. (2001), 'Koloniale vertoningen: de verbeeldingen van NederlandsIndië op de wereldtentoonstellingen (1800-1931)', unpublished $\mathrm{PhD}$ thesis, University of Amsterdam

Bloembergen, M. and R. Raben (eds) (2009), Het koloniale beschavingsoffensief wegen naar het nieuwe Indië, 1890-1950, Leiden: KILTV uitgeverij

Boots, A. and R. Woortman (2009), Anton de Kom: Biografie 1898-1945, 1945-2009, Amsterdam: Contact

Boittin, J. A. (2010), Colonial Metropolis: The Urban Grounds of Anti-Imperialism and Feminism in Interwar Paris, Lincoln, Nebraska: University of Nebraska Press

Britton, S. (2010), '“Come and see the empire by the all red route!” : Anti-imperialism and exhibitions in interwar Britain', History Workshop Journal, 69 (1), 68-89

Carr, E. H. (1983), Twilight of the Comintern, London: MacMillan

Ezra, E. (2000), The Colonial Unconscious: Race and culture in interwar France, Ithaca; London: Cornell University Press

Fatah-Black, K. (2017), 'Rode Deletie: De verstomde herinnering aan het communisme van Anton de Kom', Tijdschrift voor geschiedenis, 130 (3), 279-83

Goebel, M. (2015), Anti-Imperial Metropolis: Interwar Paris and the Seeds of Third World Nationalism, Cambridge: Cambridge University Press

Hoffenberg, P. H. (2001), An Empire on Display: English, Indian and Australian Exhibitions from the Crystal Palace to the Great War, Berkeley: University of California Press

Kuykendall, R. (2002), 'African blood brotherhood, independent Marxist during the Harlem renaissance', Western Journal of Black Studies, 26 (1), 16-21

Morton, P. A. (2000), Hybrid Modernities: Architecture and Representation at the 1931 Colonial Exposition, Paris, Cambridge: MIT Press

Noonan, M. (2017), Marxist Theories of Imperialism, A History, London; New York: I.

B. Taurus 
Oostindie, G. and E. Maduro (1986), In het land van de overheerser: Antillianen en Surinamers in Nederland, 1634/1667-1954, 2 vols, Dordrecht: Floris

Palermo, L. (2009), 'L'exposition anticoloniale: Political or aesthetic protest?' French Cultural Studies, 20 (1), 27-46

Parliament.com (2019), 'L.L.H. (Lou) de Visser', available at https://www.parlement.com/id/vg091lc23faf/1_ 1 h_lou_de_visser, accessed 10 March 2019

Perthus, M. (1976), Henk Sneevliet: Revolutionair-socialist in Europa en Azië, Nijmegen: SUN

Petersson, F. (2013), Willi Münzenberg, the League against Imperialism, and the Comintern, 1925-1933, 2 vols, New York: Edwin Mellon Press

Petersson, F. (2014), 'Hub of the anti-imperialist movement', Interventions, 16 (1), 4971.

Poeze, H. (1989), 'Indonesians at Leiden University', in Otterspeer, W. (ed.), Leiden Oriental Connections, 1850-1940, New York: Brill, 250-79

Poeze, H., C. van Dijk, I. van der Meulen (1986), In het land van de overheerser: Indonesiërs in Nederland, 2 vols, Dordrecht: Floris

Ramaer, H. (1983), 'Anarchisme in Nederland: continuiteit en verandering van een sociale beweging', unpublished MA thesis, Erasmus University Rotterdam

Steinberg, M. (1998), 'Tilting the frame: Considerations on collective action framing from a discursive turn', Theory and Society, 27 (4), 845-72

Stutje, K. (2015a), 'The complex world of the Chung Hwa Hui: International engagements of Chinese Indonesian: Peranakan students in the Netherlands, 19181931', Journal of the Humanities and Social Sciences of Southeast Asia and Oceania, $171(4), 516-42$

Stutje, K. (2015b), 'To maintain an independent course: Inter-war Indonesian nationalism and international communism on a Dutch-European stage', Dutch Crossing, 39 (3), 204-20 
Stutje, K. (2017), 'Volk van Java, de Russische Revolutie houdt ook lessen in voor U', Tijdschrift voor Geschiedenis, 130 (3), 427-47

Tarrow, S. (1993), 'Cycles of collective action: Between moments of madness and the repertoire of contention', Social Science History, 17 (2), 281-307

Tilly, C. (2017), 'From mobilization to revolution', in Castaneda, E. and C. L. Schneider (eds), Collective Violence, Contentious Politics, and Social Change: A Charles Tilly Reader, New York: Routledge

Van Sijl, C. (2001), 'Nabrink, Gerard. Biografisch Woordenboek van het Socialisme en de Arbeidersbeweging in Nederland', Biografisch Woordenboek van het Socialisme en de Arbeidersbeweging in Nederland (BWSA) available at https://socialhistory.org/bwsa/biografie/nabrink, accessed 17 March 2019

Voerman, G. (2001) De Meridiaan van Moskou: de CPN en de Communistische Internationale, Amsterdam: Veen

Wielinga, F. (2015), A History of the Netherlands: from the Sixteenth Century to the Present Day, London: Bloomsbury

Young, R. (2016), Postcolonialism: An Historical Introduction, Anniversary Edition, Chichester: Wiley Blackwell

To cite this paper please use the following details: Kuijt, M. (2019), 'Exposing the Colonial Exhibition: Dutch Anti-Colonial Activism in a Transnational Context', Reinvention: an International Journal of Undergraduate Research, Volume 12, Issue 2, https://reinventionjournal.org/article/view/486. Date accessed [insert date]. If you cite this article or use it in any teaching or other related activities please let us know by emailing us at Reinventionjournal@warwick.ac.uk. 